\title{
THE ASSOCIATION BETWEEN SELECTION'S ASSESSMENT ITEMS AND RESIDENT'S PERFORMANCES IN THE OPHTHALMOLOGY DEPARTMENT OF A FACULTY OF MEDICINE
}

\author{
Syntia Nusanti ${ }^{1 *}$, Anwar Jusuf ${ }^{1}$, Aria Kekalih $^{1}$ \\ ${ }^{1}$ Faculty of Medicine, Universitas Indonesia/RSUPN Dr. Cipto Mangunkusumo, Jakarta - INDONESIA
}

Submitted: 17 Jan 2019; Final Revision from Author: 03 Mar 2020; Accepted: 16 Mar 2020

\begin{abstract}
Background: The admission of residency program in the Ophthalmology Department, FKUI-RSCM is based on the accumulative score from some of the selection's assessment items. The coordinator expects the candidates who received high marks on selection process would also give excellent performance during the residency and therefore the resident would graduate as a qualified ophthalmologist. The aim of this study is to know the association between selection's assessment items and the performance during the residency program.

Methods: This was a retrospective cross-sectional study using secondary data. The inclusion criteria were all ophthalmology residents with complete data information of selection, during, and at the end of the residency program from 1999 to 2006, in which results in 101 subjects. The selection data collection includes gender, age, the medical faculty origin, interview result, psychological test result, the entrance examination result, and the selection result. Data during the residency program involve the result from each end of the program's step, result of national examination, and difficulties encountered during the residency program. And lastly, data at the end of the residency program are the GPA and the duration of the residency. Results: There was a significant correlation between the residents' medical faculty origin and their results at the end of each step ( $p=0.004)$. There were also significant correlations between age $(p=0.004)$, medical faculty origin $(p=0.008)$, selection result $(p=0.002)$ and their final GPA. Gender also have a significant correlation with difficulties encountered during the residency program ( $p=0.001$ ). No significant correlation found between selection's assessment items and duration of the residency.

Conclusion: There were some significant correlations between some selection's criteria and the performance of ophthalmology residency program's participants. The medical faculty origin was found to be the strongest predictor to predict the performance of the residents.
\end{abstract}

Keywords: Selection, Ophthalmologist, Selection's assessment items, Performance, Residency

\section{ABSTRAK}

Latar belakang: Penerimaan peserta Program Pendidikan Dokter Spesialis Mata (PPDS) di departemen Ilmu Kesehatan Mata FKUI-RSCM adalah berdasarkan jumlah nilai dari beberapa butir penilaian seleksi yang ditentukan saat penerimaan. Pada proses tersebut diharapkan ada butir penilaian seleksi yang dapat menjadi prediktor untuk melihat kemampuan pada saat pendidikan dan hasil akhir pendidikan. Tujuan penelitian adalah mencari hubungan antara butir penilaian seleksi dengan performa pada saat pendidikan dan hasil akhir pendidikan.

$\overline{\text { *corresponding author, contact: syntia_nusanti@hotmail.com }}$ 
Metode: Penelitian ini merupakan penelitian retrospektif potong lintang dengan menggunakan data sekunder. Kriteria inklusi adalah semua peserta program pendidikan dokter spesialis mata dari tahun 1999 sampai 2006 dengan data seleksi, data selama pendidikan, dan data keluar yang lengkap yaitu sejumlah 101 subjek. Data seleksi yang dikumpulkan adalah jenis kelamin, usia, asal fakultas kedokteran, hasil wawancara, hasil psikotest, nilai ujian masuk, dan nilai seleksi. Data selama pendidikan adalah nilai kenaikan tahap, nilai ujian nasional, dan masalah saat pendidikan. Sedangkan data keluar yang dikumpulkan adalah IPK dan masa pendidikan.

Hasil: Didapatkan hubungan yang bermakna antar asal fakultas kedokteran $(\mathrm{p}=0,004)$ dengan nilai kenaikan tahapnya. Didapatkan hubungan yang bermakna antara usia $(\mathrm{p}=0,004)$, asal FK $(\mathrm{p}=0,008)$, dan nilai seleksi $(\mathrm{p}=0,002)$ dengan IPK akhir. Jenis kelamin memiliki hubungan yang bermakna dengan masalah saat pendidikan $(\mathrm{p}=0,001)$. Tidak didapatkan hubungan yang bermakna antara butir seleksi dengan masa pendidikan.

Kesimpulan: Didapatkan hubungkan yang bermakna antara beberapa kriteria seleksi dengan performa peserta program. Asal fakultas kedokteran merupakan prediktor paling kuat untuk memprediksi performa peserta didik.

Kata kunci: seleksi, spesialis mata, butir penerimaan, performa, peserta didik

\section{PRACTICE POINTS}

- To determine the standard of selection's assessment items related with resident's performance.

- To improve resident's performance based on their selection's assessment.

\section{PENDAHULUAN}

Masalah kebutaan di Indonesia masih merupakan masalah sosial sesuai dengan kriteria WHO. ${ }^{1}$ Masalah sosial yang sedemikian besar tersebut membutuhkan penanganan yang lebih serius yang melibatkan semua pihak baik pihak pemerintah, masyarakat dan dokter spesialis mata. Dari sisi dokter spesialis mata tidak hanya dibutuhkan jumlah namun juga kualitas dokter spesialis mata yang baik. Untuk mencapai kualitas seorang dokter spesialis mata yang baik diperlukan kurikulum yang baik dalam sistem pengajarannya. Apabila sudah tersedia kurikulum yang sesuai dan dapat diharapkan mencetak seorang dokter mata sesuai yang dibutuhkan oleh masyarakat maka langkah selanjutnya adalah mendapatkan bibit unggul yang dapat menjalani kurikulum pendidikan dengan baik dan nantinya tidak menemukan kesulitan yang berarti baik dalam masa pendidikannya maupun saat sudah menjadi seorang dokter spesialis mata. Untuk menemukan individu yang unggul tentu saja diperlukan proses seleksi dan kriteria seleksi yang valid.

Di Fakultas Kedokteran Universitas Indonesia (FKUI) penerimaan calon peserta didik untuk program spesialis pada dasarnya menggunakan metoda yang sama yaitu penilaian terhadap kemampuan akademik dan non akademik. Kriteria seleksi diserahkan sepenuhnya kepada masing-masing program studi. Setiap program studi pendidikan dokter spesialis memakai metoda yang berbeda dan kriteria pemilihan yang berbeda pula.

Evaluasi terhadap proses seleksi haruslah dilakukan karena seringkali proses seleksi ini dipertanyakan kesahihannya sehingga panitia seleksi harus mampu mempertahankan metoda seleksi yang dipakai. Selain itu, seleksi yang kita tetapkan harus mampu memprediksi performa kandidat di masa datang. ${ }^{2}$

Selama ini penerimaan peserta Program Pendidikan Dokter Spesialis Mata (PPDS) di departemen Ilmu Kesehatan Mata FKUI-RSCM adalah berdasarkan nilai dari beberapa faktor yang ditentukan saat penerimaan. Pengelola program pendidikan dokter spesialis mata mengharapkan calon peserta PPDS yang memiliki hasil nilai seleksi yang tinggi akan memberikan hasil yang memuaskan pada saat pendidikan sehingga dapat menjadi dokter spesialis mata yang berkualitas dan mampu meningkatkan nilai akreditasi institusi pendidikan. Namun pada 
kenyataannya, tidak selalu peserta didik yang memiliki nilai tertinggi pada saat seleksi menunjukkan hasil yang memuaskan pada saat menjalani proses pendidikan. Seringkali bahkan peserta tersebut membutuhkan masa belajar yang lebih panjang dibanding peserta lain dan menghadapi kesulitan saat menjalani proses pendidikan. Pengelola pendidikan mengharapkan ada faktor penilaian seleksi yang dapat menjadi prediktor untuk melihat kemampuan pada saat pendidikan dan hasil akhir pendidikan sehingga dapat membantu untuk mengambil keputusan calon peserta mana yang kemungkinan dapat menunjukkan performa yang terbaik saat pendidikan dan memberikan hasil yang baik pula.

Sehingga, pada penelitian ini, dirumuskan pertanyaan "Kriteria seleksi manakah yang dapat menjadi prediktor performa peserta PPDS ilmu kesehatan mata?" Tujuan penelitian ini adalah untuk mencari hubungan antara faktor-faktor penilaian seleksi dengan performa pada saat pendidikan yang dilihat dari nilai ujian tiap tahap dan kesulitan yang dihadapi selama masa pendidikan dan hasil akhir.

\section{METODE}

Penelitian ini menggunakan desain retrospektif potong lintang yang dilakukan pada bulan Mei sampai Juni 2011 di Departemen Ilmu Kesehatan Mata FKUI-RSCM. Populasi penelitian ini adalah peserta pendidikan dokter spesialis mata yang diterima pada tahun 1999 sampai tahun 2006. Pengambilan sampel menggunakan metode sampel total (total sampling) yaitu peserta program pendidikan yang diterima pada program pendidikan dokter spesialis mata dari tahun 1999 sampai 2006 dan telah menyelesaikan masa pendidikannya. Kriteria inklusi adalah semua peserta PPDS dari tahun 1999 hingga 2006 yang sudah lulus. Sedangkan, kriteria eksklusi yang ditetapkan adalah sampel dengan data yang tidak lengkap. Penelitian telah mendapatkan persetujuan dari komisi ethical clearance FKUI.

Variabel yang digunakan pada penelitian secara statistik dibedakan menjadi jenis kategorik dan numerik. Variabel kategorik antara lain umur, jenis kelamin, hasil wawancara, hasil psikotes, asal fakultas kedokteran, nilai ujian masuk, serta masalah yang dihadapi saat pendidikan. Sedangkan variabel numerik antara lain nilai seleksi, nilai tahap I, II, III, Indeks Prestasi Kumulatif (IPK), masa pendidikan, nilai ujian tulis nasional, nilai ujian diagnostik nasional, dan nilai ujian bedah nasional.

Penelitian ini menggunakan data sekunder dari sekertariat pendidikan residensi. Pengolahan data dilakukan dengan menggunakan SPSS versi 11.0. Tahap deskriptif dilakukan untuk menyajikan data tiap variabel dalam bentuk narasi dan tabel. Data kategorik ditampilkan dalam bentuk tabel frekuensi, sedangkan data numerik dijelaskan dalam bentuk nilai tengah (rata-rata atau median) dan dispersi (standar deviasi, minimum dan maksimum). Sebaran data numerik akan dianalisis menggunakan uji Kolmogorov Smirnov dengan batasan $p>0,05$ untuk sebaran data normal.

Pada tahap analitik dilakukan uji bivariat kemudian multivariat untuk mengetahui hubungan antara faktor seleksi dengan hasil akhir. Uji bivariat yang digunakan adalah uji perbandingan proporsi (Chi square) uji korelasi, dan uji perbandingan rerata (uji T). Untuk hasil akhir yang berupa penilaian berulang yaitu nilai setiap tahap akan digunakan uji General Linear Model for Repeated Measure. Faktor seleksi dengan hasil uji bivariat yang memenuhi kriteria multivariat $(p<0,25)$ dimasukkan pada uji regresi linear dan logistik multipel untuk mendapatkan faktor yang paling dominan.

\section{HASIL DAN PEMBAHASAN}

\section{Karakteristik subjek penelitian}

Pada penelitian ini didapatkan 101 subjek yang memenuhi kriteria inklusi untuk diikutsertakan dalam penelitian. Data karakteristik subjek sesuai dengan butir-butir kriteria seleksi tampak pada Tabel 1. 
Tabel 1. Karakteristik subjek berdasarkan butir-butir seleksi

\begin{tabular}{lc}
\multicolumn{1}{c}{ Variabel } & $\begin{array}{c}\text { Frekuensi }(\%) / \\
\text { Mean(SD) }\end{array}$ \\
Jenis Kelamin & \\
$\quad$ Laki-laki & $32,6 \%$ \\
Perempuan & $67,4 \%$ \\
Asal Fakultas Kedokteran & \\
FK negeri yang sama & $59,3 \%$ \\
FK negeri selain FK UI & $23,3 \%$ \\
FK swasta & $17,4 \%$ \\
Hasil Psikotest & \\
Disarankan & $51,2 \%$ \\
Dipertimbangkan untuk disarankan & $25,6 \%$ \\
Tidak disarankan & $23,3 \%$ \\
Nilai Ujian Masuk & \\
$<70$ & $72 \%$ \\
$70-79$ & $28 \%$ \\
$\geq 80$ & 0 \\
Usia & $28,79(3,351)$ \\
Nilai Seleksi & $24,5(3,619)$ \\
\hline
\end{tabular}

Pada Tabel 1, subjek perempuan lebih banyak $(67,4 \%)$ dibandingkan laki-laki $(32,6 \%)$ dengan rerata usia $28,79(3,351)$ tahun. Sebanyak 59,3\% peserta didik berasal dari FK negeri yang sama. Untuk hasil wawancara didapatkan proporsi yang tidak seimbang. Hanya satu orang subjek penelitian yang tidak disarankan, sehingga untuk butir seleksi ini tidak diikutsertakan lagi dalam analisa selanjutnya.

Berdasarkan performa tercatat ada masalah saat pendidikan pada subjek sebanyak 61 subjek $(60,5 \%)$, sedangkan rerata IPK akhir adalah 3,18 $(0,225)$ dan masa pendidikan 49,48 (5,893). Tampak adanya kenaikan rerata nilai tiap tahap yaitu nilai tahap I
67,952 (2,967) dibandingkan nilai tahap II 68,486 $(3,509)$, dan dibandingkan nilai tahap III 75,265 $(5,061)$. Rata-rata nilai ujian bedah paling tinggi yaitu $85,83(6,83)$ dibandingkan nilai ujian tulis diagnostik nasional $80.031(6,386)$ dan nilai ujian tulis nasional $68,497(8,95)$.

\section{Penilaian terhadap performa akhir}

Uji chi square dipakai untuk menilai hubungan antara masalah saat pendidikan dengan masingmasing butir kriteria seleksi. Didapatkan hasil yang bermakna $(p=0,001)$ antara jenis kelamin dengan masalah saat pendidikan. 
Tabel 2. Hubungan antara butir-butir pada kriteria seleksi dengan masalah saat pendidikan

\begin{tabular}{|c|c|c|c|c|}
\hline \multirow{2}{*}{ Variabel } & & \multicolumn{2}{|c|}{ Masalah (\%) } & \multirow{2}{*}{ Nilai $\mathrm{p}$} \\
\hline & & Tidak ada & Ada & \\
\hline \multirow[t]{3}{*}{ Hasil Psikotest } & Disarankan & 61,4 & 38,6 & \multirow{3}{*}{0,775} \\
\hline & Dipertimbangkan untuk disarankan & 54,5 & 45,5 & \\
\hline & Tidak disarankan & 65 & 35 & \\
\hline Jenis kelamin & Laki-laki & 35,7 & 64,3 & \multirow[t]{2}{*}{0,001} \\
\hline & Perempuan & 72,4 & 27,6 & \\
\hline Asal Fakultas & FK negeri yang sama & 68,6 & 31,4 & \multirow{3}{*}{0,117} \\
\hline Kedokteran & FK negeri lain & 55 & 45 & \\
\hline & FK swasta & 40 & 60 & \\
\hline \multirow[t]{2}{*}{ Nilai Ujian Masuk } & $<70$ & 61,2 & 38,8 & \multirow[b]{2}{*}{0,811} \\
\hline & $70-79$ & 58,3 & 41,7 & \\
\hline \multirow[t]{2}{*}{ Usia } & $<30$ tahun & 62,2 & 37,8 & \multirow[t]{2}{*}{0,821} \\
\hline & $30-35$ tahun & 57,5 & 42,5 & \\
\hline
\end{tabular}

Uji t digunakan untuk menilai hubungan antara nilai seleksi dan masalah pendidikan dan didapatkan hasil yang tidak bermakna dengan nilai $\mathrm{p}<0.690$.

Untuk menilai hubungan antara tiap butir seleksi dengan dengan IPK akhir, masa pendidikan dan hasil ujian nasional dilakukan uji perbandingan dengan menggunakan uji t dan anova. Hasil ditampilkan pada tabel 3. Usia $(p=0,004)$ dan asal FK $(0,008)$ memberikan hubungan yang bermakna dengan IPK akhir. Subjek dengan usia kurang dari 30 tahun memiliki rerata IPK yang lebih tinggi, hasil yang sama ditemukan pada subjek yang berasal dari FK negeri yang sama. Subjek perempuan memiliki rerata IPK yang lebih tinggi dibandingkan laki-laki. Hasil psikotest menunjukan tidak ada hubungan yang bermakna secara statistik antara kelompok subjek yang disarankan dengan yang tidak disarankan terhadap hasil IPK akhir.

Tidak ditemukan adanya hubungan yang bermakna secara statistik antara masa pendidikan dengan butirbutir pada kriteria seleksi. Laki-laki memiliki rerata masa pendidikan yang lebih panjang dibandingkan dengan perempuan yaitu 50,93 bulan dibandingkan dengan 48,78 bulan.

Usia kurang dari 30 tahun memiliki rerata nilai ujian tulis nasional yang lebih tinggi yaitu 70,54 dibandingkan dengan usia 30-35 tahun dan bermakna secara statistik $(p=0,006)$. Subjek penelitian yang berasal dari FKUI menghasilkan rerata nilai ujian tulis nasional yang lebih tinggi yaitu 72,28 dibandingankan dengan subjek yang berasal dari FK lain dengan nilai $p<0,001$. Variabel jenis kelamin menunjukan kecenderungan bahwa perempuan memiliki rerata nilai ujian tulis yang lebih tinggi dibandingkan laki-laki namun tidak bermakna secara statistik.

Asal FK memberikan hubungan yang bermakna dengan hasil ujian diagnostik nasional seperti tampak pada tabel 3. Subjek penelitian yang berasal dari FK negeri selain FK UI memberikan hasil ujian diagnostik yang lebih tinggi. Hasil post-hoc analisa menunjukan bahwa tidak terdapat perbedaan yang bermakna antara subjek penelitian yang berasal dari FK negeri yang sama dan subjek penelitian yang berasal dari FK negeri lain. Sedangkan antara FK negeri yang sama dan FK negeri selain FK UI dengan FK swasta terdapat perbedaan yang bermakna $\mathrm{p}<$ 0.019 .

Terdapat kecenderungan subjek perempuan memiliki rerata nilai ujian masuk yang lebih tinggi dibandingkan laki-laki dan subjek dengan nilai ujian masuk antara 70-79 memiliki rerata nilai ujian diagnostik yang lebih tinggi dibandingkan dengan subjek dengan nilai ujian kurang dari 70. Namun keduanya tidak bermakna secara statistik. 
Tabel 3. Hubungan antara IPK akhir dengan butir-butir seleksi

\begin{tabular}{|c|c|c|c|c|c|c|c|c|c|c|}
\hline Butir-butir seleksi & $\begin{array}{c}\text { IPK akhir } \\
\text { Mean (SD) }\end{array}$ & Nilai $p$ & $\begin{array}{c}\text { Masa } \\
\text { pendidikan } \\
\text { dalam bulan } \\
\text { Mean (SD) }\end{array}$ & $\begin{array}{c}\text { Nilai } \\
\mathrm{p}\end{array}$ & $\begin{array}{c}\text { Nilai } \\
\text { ujian tulis } \\
\text { nasional } \\
\text { Mean } \\
\text { (SD) }\end{array}$ & Nilai $\mathrm{p}$ & $\begin{array}{l}\text { Nilai ujian } \\
\text { diagnostik } \\
\text { Mean(SD) }\end{array}$ & Nilai $p$ & $\begin{array}{l}\text { Nilai ujian } \\
\text { bedah } \\
\text { nasional } \\
\text { Mean (SD) }\end{array}$ & $\begin{array}{c}\text { Nilai } \\
\mathrm{p}\end{array}$ \\
\hline $\begin{array}{l}\text { Jenis Kelamin } \\
\text { Laki-laki } \\
\text { Perempuan }\end{array}$ & $\begin{array}{c}3,178(0,176) \\
3,184 \\
(0,247)\end{array}$ & 0,918 & $\begin{array}{l}50,93 \\
(5,95) \\
48,78 \\
(5,78)\end{array}$ & 0,113 & $\begin{array}{l}66,35 \\
(9,40) \\
69,53 \\
(8,61)\end{array}$ & 0,123 & $\begin{array}{l}79,08 \\
(5,84) \\
80,49 \\
(6,63)\end{array}$ & 0,341 & $\begin{array}{l}86,75 \\
(5,34) \\
85,39 \\
(7,44)\end{array}$ & 0,390 \\
\hline $\begin{array}{l}\text { Usia } \\
<30 \text { tahun } \\
\text { 30-35 tahun }\end{array}$ & $\begin{array}{c}3,236 \\
(0,214) \\
3,095 \\
(0,218)\end{array}$ & 0,004 & $\begin{array}{l}49,55 \\
(6,49) \\
49,36 \\
(4,86)\end{array}$ & 0,889 & $\begin{array}{l}70,54 \\
(8,63) \\
65,21 \\
(8,58)\end{array}$ & 0,006 & $\begin{array}{l}80,50 \\
(5,88) \\
79,27 \\
(7,15)\end{array}$ & 0,390 & $\begin{array}{l}86,34 \\
(6,34) \\
85,01 \\
(7,57)\end{array}$ & 0,382 \\
\hline $\begin{array}{l}\text { Nilai Ujian Masuk } \\
70-79 \text { tahun } \\
<70 \text { tahun }\end{array}$ & $\begin{array}{c}3,181 \\
(0,210) \\
3,185 \\
(0,266)\end{array}$ & 0,944 & $\begin{array}{l}49,81 \\
(6,18) \\
48,63 \\
(5,07)\end{array}$ & 0,407 & $\begin{array}{l}68,47 \\
(9,04) \\
68,56 \\
(8,88)\end{array}$ & 0,965 & $\begin{array}{l}80,58 \\
(6,32) \\
78,61 \\
(6,46)\end{array}$ & 0,230 & $\begin{array}{l}85,97 \\
(6,32) \\
85,46 \\
(6,96)\end{array}$ & 0,764 \\
\hline $\begin{array}{l}\text { Asal Fakultas } \\
\text { Kedokteran } \\
\text { FK negeri yang } \\
\text { sama } \\
\text { FK negeri lain } \\
\text { FK swasta }\end{array}$ & $\begin{array}{c}3,241 \\
(0,207) \\
3,126 \\
(0,217) \\
3,056 \\
(0,237)\end{array}$ & 0,008 & $\begin{array}{l}49,14 \\
(6,38) \\
50,90 \\
(5,07) \\
48,73 \\
(5,12)\end{array}$ & 0,460 & $\begin{array}{l}72,28 \\
(6,99) \\
63,79 \\
(8,57) \\
61,88 \\
(9,02)\end{array}$ & $<0.001$ & $\begin{array}{l}80,51 \\
(6,04) \\
81,82 \\
(6,01) \\
76,03 \\
(6,76)\end{array}$ & 0,019 & $\begin{array}{l}86,74 \\
(5,36) \\
84,35 \\
(9,34) \\
84,72 \\
(7,39)\end{array}$ & 0,330 \\
\hline $\begin{array}{l}\text { Hasil Psikotest } \\
\text { Disarankan }\end{array}$ & 3,204 & 0,602 & 49,75 & 0,888 & 69,69 & 0,305 & 80,38 & 0,738 & 86,52 & 0,610 \\
\hline $\begin{array}{l}\text { Dipertimbangkan } \\
\text { Tidak } \\
\text { disarankan }\end{array}$ & $\begin{array}{c}3,172 \\
(0,266) \\
3,056 \\
(0,239)\end{array}$ & & $\begin{array}{l}49,00 \\
(6,90) \\
49,40 \\
(4,38)\end{array}$ & & $\begin{array}{l}68,40 \\
(9,44) \\
65,95 \\
(9,73)\end{array}$ & & $\begin{array}{l}80,22 \\
(4,89) \\
79,05 \\
(7,66)\end{array}$ & & $\begin{array}{l}84,82 \\
(6,35) \\
85,43 \\
(9,51)\end{array}$ & \\
\hline
\end{tabular}

Tabel 4. Hasil uji korelasi antara nilai seleksi, usia, dengan performa pendidikan

\begin{tabular}{lccccc} 
& $\begin{array}{c}\text { IPK akhir } \\
\mathrm{p}(\mathrm{r})\end{array}$ & $\begin{array}{c}\text { Masa } \\
\text { pendidikan }\end{array}$ & Ujian tulis nasional & $\begin{array}{c}\text { Ujian diagnostik } \\
\text { nasional }\end{array}$ & $\begin{array}{c}\text { Ujian Bedah } \\
\text { Nasional }\end{array}$ \\
Nilai Seleksi & $0,002(+0,335)$ & $0,554(+0,065)$ & $0,006(+0,291)$ & $0,609(0,056)$ & $0,902(-0,14)$ \\
Usia & $0,001(-0,339)$ & $0,602(-0.054)$ & $0,002(-0,54)$ & $0,810(0,026)$ & $0,674(-0,046)$ \\
\hline
\end{tabular}


Tabel 5. Hasil uji multivariat untuk IPK akhir dan hasil ujian tulis nasional

\begin{tabular}{lc}
\multicolumn{1}{c}{ Variabel } & Nilai p \\
IPK Akhir & \\
Usia & 0,041 \\
Asal FK & 0,015 \\
Ujian Tulis Nasional & \\
Usia & 0,062 \\
Jenis Kelamin & 0,023 \\
Asal FK & $\mathrm{p}<0,001$ \\
Ujian Diagnostik & \\
Asal FK & 0,083 \\
Nilai Ujian Masuk & 0,269 \\
\hline
\end{tabular}

Tidak didapatkan hasil yang bermakna secara statistik antara hasil ujian bedah dengan butir-butir seleksi seperti tampak pada Tabel 3. Subjek lakilaki memiliki rerata hasil ujian bedah nasional yang lebih tinggi dibandingkan perempuan namun tidak bermakna secara statistik.

Terdapat korelasi yang bermakna antara nilai seleksi dengan IPK akhir dan nilai ujian tulis nasional. Semakin tinggi nilai seleksi maka semakin tinggi IPK akhir dan nilai ujian tulis nasional. Didapatkan pula korelasi antara usia dengan IPK akhir dan nilai ujian tulis nasional, semakin tua usia maka IPK akhir dan nilai ujian tulis nasional akan makin rendah, seperti terlihat pada Tabel 4.

Setelah dilakukan uji bivariat untuk mengetahui hubungan masing-masing variabel dilakukan pembuatan rangkuman terhadap hasil-hasil uji bivariat sebagai dasar melakukan uji multivariat untuk melihat butir seleksi manakah yang memiliki hubungan yang paling bermakna. Uji multivariat dilakukan pada variabel dengan nilai $\mathrm{p}$ yang bermakna yaitu $p<0,005$ dan nilai $p<0,25$. Nilai seleksi meskipun memilikI hasil yang bermakna namun tidak dilakukan uji multivariat karena terdapat korealianitas antara nilai seleksi dengan masing-masing butir seleksi. Hal ini disebabkan karena nilai seleksi mengandung nilai masing-masing butir-butir seleksi.

Jenis kelamin memberikan hubungan yang lebih bermakna dengan asal FK. Subjek laki-laki akan memberikan kemungkinan 6 kali lebih besar mendapatkan masalah saat pendidikan dibandingkan perempuan. Sedangkan subjek penelitian yang berasal dari FK swasta akan memberikan kemungkinan 2,5 kali lebih besar mendapatkan masalah dibandingkan subjek penelitian yang berasal dari FK negeri yang sama.

Asal FK memberikan hubungan yang lebih bermakna dibandingkan dengan usia terhadap IPK akhir seperti tampak pada Tabel 5. Hal yang sama didapatkan pada hasil ujian tulis nasional dibandingkan dengan jenis kelamin dan usia.

\section{Penilaian proses}

Penilaian proses dilakukan dengan analisis menggunakan general linear measurement (GLM) dengan membandingkan nilai-nilai tiap tahap dengan masing-masing butir kriteria seleksi. Pada grafik 1 sampai 5 didapatkan nilai $\mathrm{p}$ berturut-turut $\mathrm{p}=0,830$ untuk jenis kelamin, $\mathrm{p}=0,689$ untuk hasil psikotest, $\mathrm{p}=0,149$ untuk asal $\mathrm{FK}, \mathrm{p}=0,004$ untuk usia, dan $\mathrm{p}=0,533$ untuk nilai ujian masuk. Terdapat hubungan yang terbalik antara nilai ujian masuk dengan nilai tiap tahap namun tidak bermakna secara statistik. 


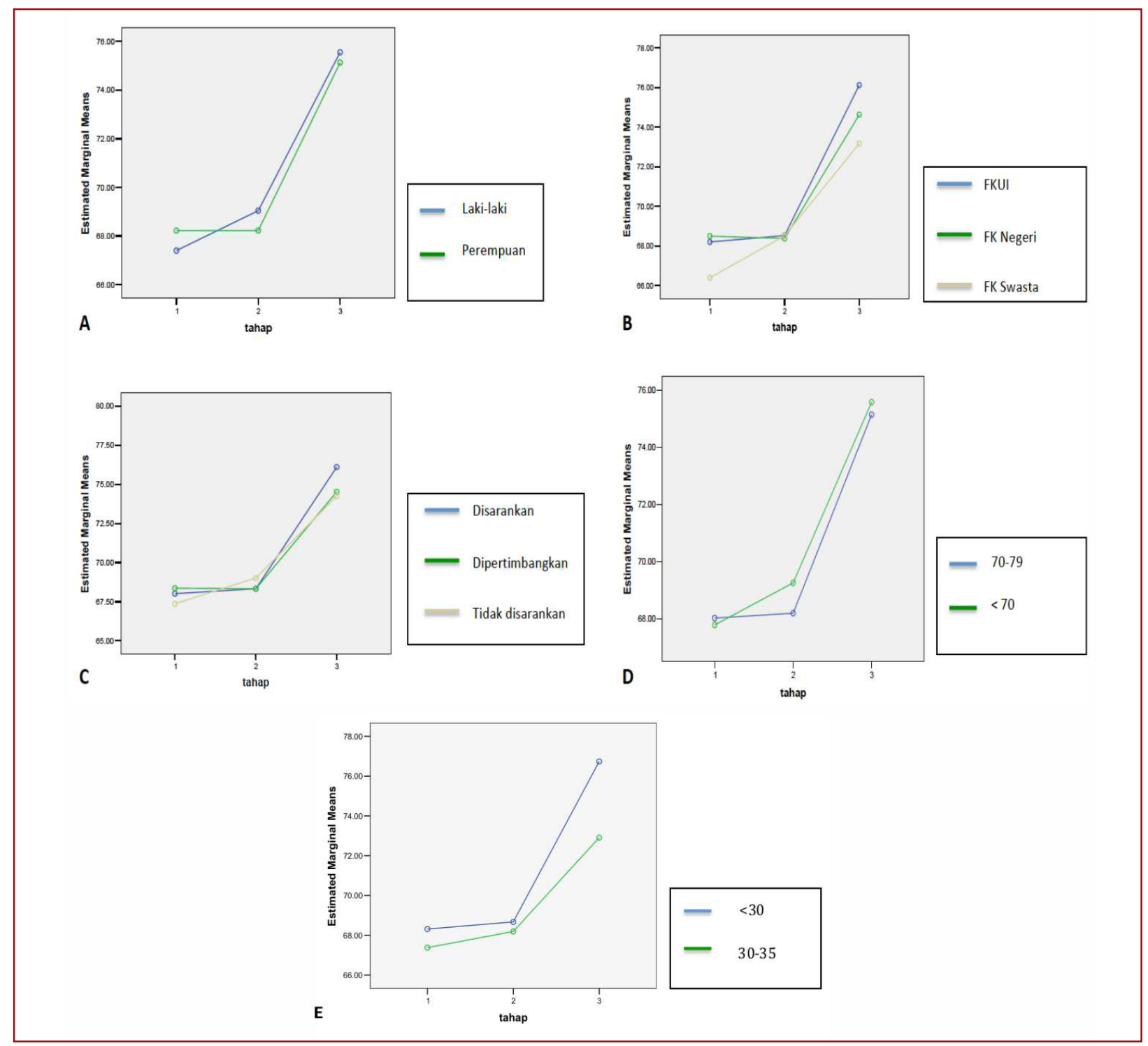

Grafik 1. Hubungan antara nilai tahap dengan: (A) jenis kelamin; (B) asal Fakultas Kedokteran; (C) hasil psikotes; (D) nilai ujian masuk; (E) usia

Uji statistik dilakukan untuk melihat signifikansi di tiap tahap pada grafik GLM yang membuka namun dengan nilai $p$ yang tidak signifikan. Pada uji ANOVA didapatkan hasil yang tidak bermakna pada setiap tahap-tahap. Analisa posthoc memberikan hasil nilai tahap I yang bermakna antara FK negeri yang sama dengan FK swasta $(p=0,037)$ dan FK negeri lain dibandingkan dengan FK swasta $(0,037)$. Sedangkan untuk nilai tahap II tidak didapatkan hasil yang bermakna. Pada nilai tahap III didapatkan perbedaan yang bermakna antara asal FK negeri yang sama dengan FK swasta.
Suatu proses seleksi dilakukan untuk mendapatkan kandidat yang terbaik dan paling sesuai dari seluruh pelamar dan diharapkan kandidat yang terpilih tersebut akan menunjukkan performa yang baik saat menjalani masa pendidikan dan memberikan hasil terbaik di akhir. Beberapa penelitian telah dilakukan untuk menilai apakah kriteria seleksi yang ditetapkan untuk memilih seorang kandidat untuk menjadi peserta didik program pendidikan dokter spesialis dapat menjadi prediktor terhadap performanya saat pendidikan dan akhir masa pendidikan. Hasil penelitian-penelitian tersebut sangat beragam, ada yang menemukan hubungan antara butir seleksi 
dengan performa, ada pula yang tidak. Pada penelitian ini salah satu butir penilaian pada proses seleksi tidak dapat dilakukan analisa apakah memiliki hubungan dengan performa dan hasil akhir atau tidak yaitu hasil wawancara. Umumnya pada setiap proses seleksi untuk menentukan calon peserta didik program pendidikan dokter spesialis, wawancara memegang peranan yang sangat penting. Namun sayangnya pada penelitian ini hal tersebut tidak dapat dievaluasi karena tentu saja kandidat dengan hasil wawancara tidak disarankan dengan sendirinya akan memiliki nilai seleksi yang lebih rendah dibandingkan dengan kandidat lain sehingga tidak diterima menjadi salah satu peserta didik karena bobot nilai wawancara lebih tinggi dibandingkan dengan butir penilaian seleksi lainnya. Beberapa penelitian terdahulu mendapatkan hasil yang beragam terhadap hubungan antara hasil wawancara dan performa. Dubovsky dkk. tidak menemukan adanya hubungan antara hasil wawancara dengan performa peserta pendidikan dokter spesialis psikiatri di universitas Buffalo New York. Hal yang sama juga didapatkan oleh Metro dkk. ${ }^{4}$ yaitu tidak terdapat hubungan yang bermakna antara hasil wawancara yang dilakukan oleh staf pengajar dengan nilai ujian pada tahap I dan akhir peserta program pendidikan dokter spesialis anestesi di universitas Pittsburgh. Hasil yang berbeda didapatkan oleh Shiroma dkk. ${ }^{5}$, Olawaiye dkk ${ }^{6}$. dan Nallasami $\mathrm{dkk}^{7}$. yang mendapatkan hubungan yang bermakna antara hasil wawancara pada saat proses seleksi dengan performa saat pendidikan dan hasil akhirnya pada program pendidikan dokter spesialis pskiatri, obstetrik dan ginekologi serta oftalmologi. Perbedaan antara ketiga penelitian terakhir dengan penelitian yang dilakukan oleh Dubovsky $\mathrm{dkk}^{3}$. dan Metro dkk. ${ }^{4}$ adalah pada ketiga penelitian terakhir wawancara dilakukan secara terstruktur dan pada salah satu penelitian tersebut data dasar kandidat tidak diberikan kepada pewancara sehingga pewancara tidak memiliki kencenderungan untuk memberikan penilaian yang lebih baik kepada kandidat dengan data dasar yang lebih baik misalnya IPK S1 atau asal fakultas kedokterannya. ${ }^{5}$

Pada penelitian ini didapatkan hubungan yang bermakna antara jenis kelamin dengan masalah saat pendidikan. Seorang peserta didik laki-laki akan memiliki kemungkinan 6 kali lebih banyak memiliki masalah saat pendidikan dibandingkan perempuan. Masalah yang umumnya timbul adalah kehadiran dan keterlambatan dalam pembuatan tugas-tugas tulis. Laki-laki akan cenderung lebih lambat dalam pembuatan tugas-tugas tulis ini dan seringkali tidak mempedulikan masalah kehadiran, padahal hal tersebut merupakan salah satu faktor penting dalam penilaian attitude. Keterlambatan pembuatan tugas-tugas tulis tentu saja akan memperpanjang masa pendidikan. Pada penelitian ini didapatkan rerata masa pendidikan peserta didik laki-laki lebih panjang dibandingkan perempuan yaitu 50,93 bulan berbanding 48,78, meskipun perbedaan tersebut tidak bermakna secara statistik. Pada proses pendidikan yaitu nilai-nilai setiap tahapnya tidak ditemukan adanya perbedaan yang bermakna antara peserta didik laki-laki dan perempuan dan tidak ditemukan adanya kecenderungan salah satu jenis kelamin memiliki nilai kenaikan tahap yang lebih tinggi. Namun pada hasil akhir ditemukan adanya perbedaan antara laki-laki dan perempuan, IPK akhir peserta didik perempuan lebih tinggi daripada laki-laki meskipun tidak bermakna secara statistik. Untuk nilai ujian nasional baik tulis maupun diagnostik ditemukan angka rerata yang lebih tinggi pada perempuan dibandingkan lakilaki. Hal yang sama didapatkan pada penelitian yang dilakukan oleh Shiroma dkk..$^{5}$ pada residen psikiatri dan Carmichael dkk. ${ }^{8}$ pada residen ortopedi. Mereka mendapatkan rerata nilai ujian nasional dan tingkat kelulusan yang lebih tinggi pada residen perempuan dibandingkan laki-laki. Suatu sistematik review yang dilakukan oleh Ferguson dkk. ${ }^{9}$ untuk menilai faktor yang mempengaruhi kesuksesan seseorang dalam menempuh pendidikan kedokteran menemukan bahwa perempuan cenderung menunjukkan performa yang lebih baik dibandingkan laki-laki pada saat pendidikannya dan mereka lebih cenderung mendapat penghargaan untuk keberhasilannya dalam pendidikan dibandingkan laki-laki. Sebuah penelitian dilakukan untuk menilai adakah perbedaan motivasi antara laki-laki dan perempuan yang mempengaruhi performa mereka saat pendidikan. Didapatkan adanya perbedaan motivasi antara perempuan dan laki-laki dalam menjalani masa pendidikanya di fakultas kedokteran, hal ini 
mungkin yang mempengaruhi hasil akhir pendidikan mereka.

Pada penelitian ini didapatkan rerata nilai ujian bedah yang lebih tinggi pada laki-laki dibandingkan dengan perempuan. Meskipun demikian tetap belum bisa disimpulkan bahwa laki-laki akan memberikan hasil operasi yang lebih baik dibandingkan perempuan karena satu-satunya data yang menyokong hal tersebut hanyalah nilai ujian bedah yang hanya dilakukan penilaian sesaat pada satu kali operasi. Perlu dilakukan penelitian lebih mendetil mengenai hal ini terhadap learning curve saat belajar melakukan operasi katarak, komplikasi yang terjadi dan hasil tajam penglihatan antara residen laki-laki dan perempuan apabila tetap akan menggunakan alasan ini untuk memberikan nilai yang lebih tinggi kepada kandidat laki-laki saat seleksi. Butir penilaian seleksi berikutnya yang dianalisa adalah usia. Pada penelitian ini didapatkan hubungan antara usia dengan pencapaian tiap tahapnya. Penelitian ini juga mendapatkan hubungan yang bermakna antara IPK akhir dan nilai ujian tulis nasional dengan usia. Pada kelompok usia yang lebih muda rerata nilai IPK akhir dan nilai ujian tulis nasional lebih tinggi dibandingkan kelompok usia yang lebih tua. Uji korelasi mendapatkan hubungan yang bermakna antara usia dengan kedua nilai tersebut. Usia makin tua akan menghasilkan nilai IPK akhir dan nilai ujian tulis yang makin rendah. Hal ini berlawanan dengan penelitian yang dilakukan Carmichael $\mathrm{dkk}^{8}$ yang menemukan residen dengan usia lebih tua memiliki rerata nilai ujian akhir yang lebih tinggi dibandingkan dengan usia lebih muda dengan batasan usia 27 tahun. Namun sesuai dengan hasil penelitian Shiroma dkk. ${ }^{5}$ yang mendapatkan bahwa usia berhubungan dengan hasil ujian nasional residen psikiatri, makin muda usia makin tinggi nilai yang dihasilkan. Hasil ini dimungkinkan bahwa kemauan untuk belajar dan motivasi yang makin menurun sesuai usia memungkinkan pencapain yang lebih rendah.

Hal lain yang memungkinkan untuk menjawab ini adalah pada subjek penelitian ini residen yang masuk kategori usia di atas 30 tahun umumnya sudah menikah yaitu 90\% dibandingan dengan 39\% $(\mathrm{p}<0,001)$. Setelah dilakukan uji statistik didapatkan hubungan yang bermakna antara status pernikahan dengan nilai ujian tulis nasional $(\mathrm{p}=0,014)$ Peserta didik yang telah menikah memiliki rerata ujian tulis nasional yang lebih rendah dibandingkan dengan peserta didik yang belum menikah, demikian pula dengan IPK akhirnya. Namun mereka memiliki rerata masa pendidikan yang lebih pendek dibandingkan dengan yang belum menikah. Kemungkinan yang bisa menjawab hal ini adalah terdapat masalah lain di luar masalah akademik yaitu masalah keluarga yang mempengaruhi dalam proses belajarnya sehingga menghasilkan nilai yang lebih rendah misalnya ketersedian waktu untuk belajar. Namun apabila dilihat dari masa pendidikannya yang lebih rendah maka pada kelompok yang menikah keinginan untuk menyelesaikan pendidikan secepat mungkin lebih besar karena ada masalah tanggung jawab dalam keluarga dan komitmen dalam hal waktu. Penelitian ini tidak mengeksplorasi lebih lanjut mengenai keberadaan anak dan masalah-masalah lain dalam keluarga yang mungkin mempengaruhi proses pendidikan. Ada baiknya dilakukan eksplorasi lebih lanjut dalam hal ini untuk melihat kemungkinan masalah-masalah lain yang berhubungan dengan pernikahan yang mempengaruhi proses dan hasil akhir pendidikan. Butir penilaian seleksi selanjutnya adalah nilai ujian masuk. Saat seorang kandidat mendaftar menjadi seorang residen maka ia harus menjalankan ujian tulis. Pembobotan nilai juga dilakukan pada butir seleksi ini yaitu nilai kurang dari 70, nilai antara 70-79 dan nilai lebih dari dan sama dengan 80 . Tidak didapatkan kandidat dengan nilai di atas 80 . Nilai ujian masuk ini pada beberapa penelitian merupakan prediktor yang kuat untuk melihat performa di masa pendidikan dan hasil akhirnya. Pada penelitian yang dilakukan Wilkinson dkk. ${ }^{10}$ didapatkan nilai ujian masuk ini memiliki korelasi yang sangat kuat dengan performa seorang mahasiswa kedokteran. Namun pada penelitian ini tidak ditemukan adanya hubungan yang bermakna antara nilai ujian masuk dengan performa bahkan pada beberapa kriteria didapatkan hasil yang terbalik. Grup dengan nilai ujian masuk yang lebih tinggi memiliki masa pendidikan yang lebih panjang, IPK akhir yang lebih rendah dan nilai ujian tulis nasional yang lebih rendah. Saat penilaian terhadap proses pendidikan yang dilihat dari grafik GLM 
tampak bahwa grup dengan nilai ujian yang lebih tinggi cenderung memiliki nilai kenaikan tahap yang lebih rendah meskipun tidak berbeda bermakna secara statistik. Hal ini membuktikan bahwa ujian tulis yang dilakukan untuk menilai kemampuan kandidat dalam hal ilmu mata tidaklah valid karena tidak dapat menjadi prediktor performanya di masa yang akan datang. Suatu instrumen evaluasi dapat dikatakan valid apabila mampu menjadi prediktor perfoma peserta ujian di masa yang akan datang. Keterbatasannya pada penelitian ini adalah nilai yang didapatkan sudah dalam bentuk kategorikal sehingga untuk menilai kecenderungan melalui uji korelasi tidak dapat dilakukan. Apabila tersedia data dalam bentuk data awal (numerik) maka akan dapat dilihat kecenderungan apakah makin tinggi nilai ujian masuk maka akan makin tinggi nilai yang didapat peserta didik atau sebaliknya.

Butir penilaian lain yang juga diteliti adalah asal fakultas kedokteran. Pada proses seleksi asal fakultas kedokteran mendapat pembobotan tersendiri. Pada penelitian ini didapatkan bahwa asal fakultas kedokteran memiliki hubungan yang bermakna secara statistik dengan IPK akhir, hasil ujian tulis nasional dan hasil ujian diagnostik namun tidak dengan masalah saat pendidikan, masa pendidikan dan hasil ujian bedah. Hasil ini berbeda dengan yang didapatkan oleh Carmichael dkk. ${ }^{8}$ yang menemukan tidak terdapatnya perbedaan yang bermakna antara residen yang berasal dari fakultas kedokteran yang sama dengan residen yang berasal dari fakultas kedokteran yang berbeda. Begitu juga dengan penelitian Boyse dkk. ${ }^{11}$ pada residen radiologi yang juga tidak mendapat hubungan yang bermakna antara asal fakultas kedokteran dengan performa residen tersebut. Pada penelitian Boyse dkk. ${ }^{11}$ juga dilakukan pembobotan terhadap asal fakultas kedokteran berdasarkan rangking fakultas tersebut secara nasional.

Terdapat beberapa pemikiran yang dapat mendasari hasil pada penelitian ini, yang pertama bahwa residen yang berasal dari fakultas kedokteran yang sama akan lebih mudah beradaptasi karena telah mengenal lingkungan belajarnya dengan baik, guruguru dan struktur pembantu lainnya dibandingkan dengan residen yang berasal dari fakultas yang berbeda. Namun apabila hal tersebut satu-satunya alasan perbedaan performa maka perbedaan tersebut harusnya hanya dapat dilihat di awal-awal masa pendidikan. Pada penelitian ini perbedaan tersebut tampak di sepanjang masa pendidikan yang terlihat pada grafik GLMnya dan pada hasil akhirnya. Alasan lainnya adalah bahwa kemungkinan peserta didik yang berasal dari FK yang sama memiliki kemampuan kognitif yang lebih tinggi, namun hal ini tidak dapat dibuktikan karena tidak didapatkan data dasar baik dalam hal IPK saat pendidikan dokter maupun tingkat intelegensianya. Mereka juga terbiasa berada dalam area kompetisi yang lebih berat, saat mereka mau masuk sebagai seorang mahasiswa maka nilai yang diharapkan untuk diterima sangat tinggi selain itu kompetisi yang dihadapi saat pendidikan juga cukup tinggi. Peserta didik yang biasa menghadapi keadaan tersebut disebut A level student, mereka terbiasa memiliki performa yang baik, memiliki kemampuan untuk mencapainya dan motivasi yang cukup untuk tinggi untuk mendapatkan hasil semaksimal mungkin. ${ }^{12}$ Performa akademik yang baik pada pendidikan dokter merupakan prediktor positif untuk pendidikan dokter spesialis. ${ }^{10}$

Butir penilaian terakhir adalah hasil psikotest yang dilakukan pada kandidat. Psikotest dilakukan untuk menilai kepribadian, sikap kerja dan kemampuan intelektual dengan hasil akhir disarankan, dipertimbangkan dan tidak disarankan. Pada penelitian ini tidak ditemukan adanya hubungan yang bermakna antara hasil psikotest dengan performa residen. Apabila dilihat dari presentasenya residen dengan hasil psikotest disarankan memiliki presentase lebih besar masalah saat pendidikan dibandingkan dengan yang tidak disarankan. Namun pada hasil akhir memang yang disarankan memiliki pencapaian yang lebih tinggi dibandingkan dengan yang tidak disarankan. Penilaian psikotest ini sebenarnya diharapkan mampu menangkap sisi lain selain kemampuan kognitif seorang kandidat. Suatu sistematik review yang dilakukan oleh Ferguson dkk. ${ }^{9}$ menemukan beberapa butir dalam pemeriksaan psikotest yang berhubungan dengan perfoma. Sebagai contoh hasil psikotest yang menunjukkan seseorang itu dominan berhubungan dengan pencapaiannya pada ujian tulis sedangkan seseorang yang memiliki 
kemampuan menggunakan data-data numerikal dan mampu berkompromi untuk mencapai suatu hal akan berhasil baik dalam ujian yang bersifat oral. Seorang yang extraversion akan memiliki tingkat keberhasilan yang tinggi pada ujian yang obejektif, sedangkan seorang yang conscientiousness akan lebih berhasil pada tugas-tugas yang bersifat tulisan. Pada penelitian ini tidak didapatkan data dasar yang mengacu pada suatu kepribadian tertentu, hanya hasil akhir yaitu disarankan, dipertimbangkan dan tidak disarankan sehingga penelitian ini tidak dapat menarik kesimpulan tertentu mengenai hubungan antara suatu hasil penilaian kepribadian tertentu dengan performa.

Pada penelitian ini didapatkan hubungan yang bermakna secara statistik antara nilai seleksi dengan IPK akhir dan nilai ujian tulis nasional. Makin tinggi nilai seleksi makin tinggi IPK akhir dan nilai ujian tulis nasional. ${ }^{10}$ Namun tidak didapatkan hubungan yang bermakna antara nilai seleksi dengan masalah saat pendidikan dan masa pendidikan. Hal yang mungkin dapat dikemukakan sebagai alasan adalah pembobotan terhadap setiap butir seleksi yang mungkin tidak sesuai. Hasil ini dapat menjadi dasar bagi pihak pengelola untuk mengkaji ulang pembobotan yang dilakukan dan mungkin menambahkan atau mengurangi butir-butir penilaian pada proses seleksi.

Untuk mengetahui butir mana yang paling memegang peranan atau menjadi prediktor yang paling baik dalam menilai performa dilakukan uji multivariat. Untuk kriteria masalah pendidikan didapatkan bahwa jenis kelamin merupakan prediktor yang lebih kuat dibandingkan dengan asal fakultas kedokteran. Laki-laki memiliki kemungkinan lebih banyak mendapatkan masalah saat pendidikan dibandingkan dengan perempuan. Seperti dikemukan pada pembahasan sebelumnya, perbedaan motivasi antara laki-laki dan perempuan mungkin menjadi salah satu alasan mengapa hal ini dapat terjadi. ${ }^{5,8}$ Asal fakultas kedokteran juga memiliki hubungan yang bermakna dengan masalah saat pendidikan namun tidak sekuat jenis kelamin. Didapatkan asal FK swasta akan memiliki kemungkinan memiliki masalah saat pendidikan dibandingkan dengan residen yang berasal dari FK negeri yang sama. Masalah yang paling sering dihadapi adalah tidak lulus ujian nasional yaitu sebesar 53\% untuk FK swasta, 35\% untuk FK negeri lain dan 3\% untuk FK UI. Hasil tersebut dapat menjadi dasar untuk pihak pengelola untuk memberikan perhatian lebih bagi peserta didik yang berasal dari FK swasta terutama pada saat akan menghadapi ujian nasional. Peran pembimbing akademik sangat penting dalam hal ini sehingga akan mengetahui terlebih dulu apabila terjadi suatu masalah di awal pendidikannya.

Uji multivariat lainnya dilakukan pada IPK akhir, hasil ujian tulis nasional dan ujian diagnostik nasional. Pada ketiganya didapatkan bahwa asal FK merupakan prediktor yang lebih kuat dibandingkan dengan usia dan jenis kelamin. Seperti telah diuraikan sebelumnya beberapa alasan bisa dikemukan untuk menjawab hal ini yaitu masalah adaptasi, motivasi, dan level A student..$^{12}$ Namun tentu saja perlu diteliti lebih lanjut dan lebih mendalam masalah perbedaan ini.

Pada setiap kriteria performa didapatkan paling tidak satu butir penilaian seleksi yang berhubungan kecuali untuk masa pendidikan dan ujian bedah. Banyak hal yang dapat mempengaruhi masa pendidikan seorang residen baik masalah akademik maupun non akademik. Untuk masalah non akademik yang diperkirakan memperpanjang masa pendidikan yaitu status pernikahan terbukti memberikan hasil yang berbeda. Residen yang sudah menikah memiliki rerata masa pendidikan yang lebih pendek dibandingkan dengan yang belum menikah. Hal ini dimungkinkan bahwa mereka yang sudah menikah cenderung berusaha mempercepat masa pendidikannya karena tanggung jawab terhadap keluarga.

Salah satu kriteria performa lainnya yang tidak memiliki hubungan dengan butir penilaian seleksi adalah nilai ujian bedah nasional. Alasan yang bisa dikemukakan adalah bahwa penilaian yang dipakai untuk menilai kemampuan operasi tersebut tidak reliabel karena tingkat subjektifitas yang tinggi atau memang tidak ditemukan adanya butir penilaian seleksi yang mampu menjadi prediktor kemampuan operasi ini. ${ }^{13}$ 


\section{KESIMPULAN}

Kesimpulan dari penelitian ini yaitu, (1) didapatkan hubungan yang bermakna antara usia dan asal fakultas kedokteran sebagai butir penilaian seleksi dengan nilai kenaikan tiap tahapnya. Usia kurang dari 30 tahun dan peserta didik yang berasal dari FK negeri yang sama memberikan hasil yang lebih baik; (2) didapatkan hubungan yang bermakna antara usia, asal FK dan nilai seleksi dengan IPK akhir. Semakin tua usia makin rendah IPK akhirnya, semakin tinggi nilai seleksi maka semakin tinggi nilai IPK akhirmya. Peserta didik yang berasal dari FK negeri yang sama memiliki nilai IPK akhir yang lebih tinggi; (3) tidak didapatkan hubungan yang bermakna antara butir penilaian seleksi dengan masa pendidikan; (4) didapatkan adanya hubungan yang bermakna antara jenis kelamin dengan masalah pada saat pendidikan. Peserta didik laki-laki memiliki kemungkinan 6 kali lebih banyak untuk mendapatkan masalah pada saat pendidikan; (5) didapatkan hubungan yang bermakna antara usia, asal FK dan nilai seleksi dengan hasil ujian tulis nasional. Semakin tua usia maka hasil ujian tulis nasional semakin rendah dan semakin tinggi nilai seleksi maka semakin tinggi pula nilai ujian tulis nasional yang dihasilkan; (6) asal fakultas kedokteran merupakan prediktor yang paling kuat untuk memprediksi performa peserta karena menghasilkan hubungan yang bermakna secara statistik lebih banyak dengan kriteria keberhasilan yaitu masalah saat pendidikan, IPK akhir dan hasil ujian tulis nasional; dan (7) tidak ditemukan adanya hubungan yang bermakna antara hasil psikotest dan ujian masuk dengan kriteria keberhasilan.

\section{DEKLARASI KEPENTINGAN}

Para penulis mendeklarasikan bahwa tidak terdapat konflik kepentingan apapun terkait studi pada naskah ini.

\section{KONTRIBUSI PENULIS}

Pada penelitian ini Syntia Nusanti, Anwar Jusuf, dan Aria Kekalih bekerja sama dalam menyusun ide penelitian, mengembangkan teori dan melakukan verifikasi dan studi analisis. Semua penulis mendiskusikan hasil penelitian dan berkontribusi dalam penulisan manuskrip.

\section{DAFTAR PUSTAKA}

1. Wolrd Health Organization. Blindness: 2020 - the global initiative for the elimination of avoidable blindness.

2. Mc Manus IC, Student Selection, In: Dent JA, Harden RM.(eds). A Practical guide for medical teachers. $3^{\text {rd }}$ ed. Edinburgh: Churcil-Livingstone; 2009.pp 371-377.

3. Dubovsky SL. Gendel MH, Dubovsky AN, Levin R, Rosse J, House R. Can Admisssion Interview predict performance in residency. Acad Psychiatry 2008;32: 498-503.

4. Metro DG. Talarico JF, Patel RM, Wetmore AL. The resident application process and its correlation to future performance as a resident. Anesth Analg 2005; 100:502-505.

5. Shiroma PR, Alarcon RD. Selection factors among international medical graduates and psychiatric residency performance. Acad Psychiatry 2010;34:128-131.

6. Olawaiye A, Yeh J, Leitch MW. Resident selection process and prediction of clinical performance in an obstetrics and gynecology program. Teaching and learning in medicine 2006; 18:310-5

7. Nallasami S, Uhler T, Nalassami N, Tapino PJ, Volpe NJ. Ophthalmology resident selection: current trend in selection criteria and improving the process. Ophthalmology 2010;117:1041-7

8. Carmichael K, Westmoreland J, Thomas J, Patterson R. Relation of residency selection factors to subseguent orthopaedic in training examination performance. Southern medical journal 2005; 98: 528-32

9. Ferguson E, James D, Madeley L. Factors associated with success in medical school: systematic review of the literature. BMJ 2002; 324: $952-7$

10. Wilkinson D, Zhang J, Byrne GJ, Luke H, Ozolins L, Parker $\mathrm{M}$ et al. Medical school selection criteriaand the prediction of academic performance. MJA 2008; 188 : 349-54

11. Boyse TD, Patterson SK, Cohan RH. Does medical school performance predict radiology 
resident performance? Acad Radiol 2002; 9 : $437-45$

12. Lynch CD, Mc Connel RJ, Hanigan A. Dental school admission in Ireland: can current selection predict success? Eur J Dent Educ 2006; 10:73-9

13. GondhowioardjoTD. Opthalmology education program in Indonesia. Presented in Asia Pacific Opthalmology meeting in Sydney, March 2011 